\title{
Everyday Leaders
}

Vicki R. TenHaken, (E-mail: tenhaken@hope.edu), Hope College

\begin{abstract}
For years business writers and speakers have focused on larger than life, charismatic Leaders, with a capital " $L$ ". The implication is that the success of an organization is dependent on this one person and his or her ability to inspire everyone else to follow a unique vision. This focus on the Leader is at least a partial cause of the lack of trust we are witnessing in business organizations today. Leaders believe they must behave in some larger than life way. With the expectation that they must see things the rest of us do not, they make riskier and riskier decisions, desperate to prove they deserve the role. Perhaps now that we have seen the problems resulting from this Leader-focused approach to running our organizations, we can return to a more reasonable approach - one that is actually attainable by mere mortals - where many are called upon to be good, competent, everyday leaders. If educational institutions begin to focus on developing the skills and character of these everyday leaders, our organizations will not only be more successful, but surely more trusted than they are today.
\end{abstract}

\subsection{Introduction}

A $\mathrm{s}$ a business executive and now as a college professor, I have for years been bothered by the focus of business writers and speakers on larger than life charismatic Leaders, with a capital "L". I believe this assumption that the success of an organization is dependent on one person and his (or occasionally, her) ability to inspire everyone else to follow his unique vision is a false one. ${ }^{1}$ We have been reading for years about the difference between managers and leaders, with managers being characterized as the unimaginative administrative implementers of a grand design developed by the Leader. Some of our most respected business writers have taken this position. According to Abraham Zaleznik in his award winning Harvard Business Review article ${ }^{2}$ on the difference between managers and leaders: managers wish to create an ordered corporate structure and are emotionally detached from their work. Leaders, in contrast, direct their energies toward introducing new approaches and ideas. Warren Bennis, best-selling author on the topic of leadership, says: "I tend to think of the differences between leaders and managers as the differences between those who master the context and those who surrender to it. There are other differences, as well, and they are enormous and crucial:

- $\quad$ The manager administers; the leader innovates.

- The manager is a copy; the leader is an original.

- $\quad$ The manager maintains; the leader develops.

- $\quad$ The manager focuses on systems and structure; the leader focuses on people.

- $\quad$ The manager relies on control; the leader inspires trust.

- $\quad$ The manager has a short-range view; the leader has a long-range perspective.

- $\quad$ The manager asks how and when; the leader asks what and why.

- $\quad$ The manager has his eye always on the bottom line; the leader has his eye on the horizon.

- $\quad$ The manager imitates; the leader originates.

- $\quad$ The manager accepts the status quo; the leader challenges it.

- $\quad$ The manager is the classic good soldier; the leader is his own person.

- The manager does things right; the leader does the right thing."3

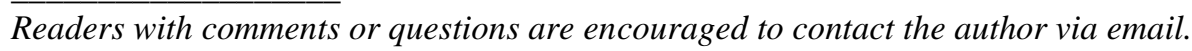


Given these types of views, is it any wonder no one wanted to be considered a mere manager? Are we surprised that the leaders of our organizations aspire to be "charismatic visionaries?"

\subsection{The Problem Caused By Focusing On Charismatic Leaders}

I believe this focus on charismatic leaders ${ }^{4}$ is part of what has brought about the lack of trust in and respect for American business today. We have put our leaders on a pedestal and in response, they believe they are expected to lead in some larger than life way. "During the 1980s and 1990s, business and the press collaborated in the creation of a mythical creature - the Superstar CEO, epitomized by [Jack] Welch. Superstar CEOs were deemed capable of single-handedly revolutionizing companies with tens or even hundreds of thousands of employees." 5 With the expectation that they be visionaries who see things the rest of us do not, these leaders begin to make riskier and riskier decisions that get played out in a competitive zeal to "win" at any cost. This approach supports cultures that admire risk-takers and rule-benders. Executives in organizations such as Enron operated in a social environment where rebels were glorified or applauded as pioneers and, as a result, they began to believe that the rules did not apply to them. ${ }^{6}$

In the 1960s and 1970s the term leadership was rarely used. We talked about managers and managing, but leadership was seen as something more about personality and not much to do with professional skills. Then James McGregor Burns published his book, Leadership, in 1978 in which he characterized "transformational leaders" as visionaries who challenge people to achieve exceptionally high levels of motivation and performance. ${ }^{7}$ Only leaders would be capable of charting necessary new courses for modern organizations, because they are "masters of change." Thus the 1980s saw the idea of leadership emerge, when writers started describing leaders as being distinguished from pedestrian managers. Leaders were the people who brought energy and spirit into play. ${ }^{8}$ The late 1980 s and early 1990s raised the bar even higher. The emphasis during these years on "reinventing" the corporation reinforced the need for a leader as "change agent" and someone with "vision." "The new corporate leadership that began emerging in the 1980s was in many ways a throwback to the swashbuckling robber barons of the late nineteenth century," says Rakesh Khurana in his research on organizational searches for charismatic CEOs. These new organizational heads were no longer defined as 'professional managers' but instead as 'leaders,' whose ability to lead was rooted in their personal characteristics, or more specifically, their charisma. ${ }^{10}$

"The turn toward charismatic authority in business, while in part a reaction to a rapidly changing economic and business environment, was also reinforced by a changing cultural context." ${ }^{11}$ Sociologist Max Weber described the charismatic leader, in his purest form, as being viewed uncritically by followers, being regarded as all-powerful and all-wise. ${ }^{12}$ Though this ideal type is unlikely to be found in actual situations, with today's expectations that corporate leaders will have a grand vision to inspire their constituents, more and more CEOs patterned themselves on the charismatic model, attainable or not. This 'charismatic CEO' stands in stark contrast to the dutiful, professional "organization man" of earlier decades described in William Whyte's classic text The Organization Man. ${ }^{13}$ In the 1980s and 1990s, the pages of Business Week, FORTUNE, and Forbes were filled with stories about heroic leadership and the personal characteristics displayed by these leaders. ${ }^{14}$

The question is, does this attention to leaders and leadership (as compared to managers and management) serve us? Is anyone capable of providing the type of larger-than-life Leadership sought after in this new model? Is the current crisis of confidence in our business organizations about the failing of people in power, or is the problem in what we have come to expect of our leaders? I believe it is both.

According to Peter Senge, this view of Leaders with a capital "L" is deeply rooted in an individualistic and non-systemic worldview. He says we see "leaders are heroes - great men (and occasionally women) who rise to the fore in times of crisis. So long as such myths prevail, they reinforce a focus on short-term events and charismatic heroes rather than on systemic forces and collective learning." 15

Not only have superstar CEOs not turned out to be the saviors of our organizations, research conducted by Harvard professor Rakesh Khurana shows that they may actually do more harm than good. ${ }^{16}$ Why would a leader who exhibits all those traits we've recently been led to believe are necessary to rise from mere 'managerhood' to 
Leadership be bad for a company? You may get a temporary burst of performance under a charismatic CEO, says Khurana, but they tend not to do a company any good in the long run. In some circumstances, the presence of a charismatic leader actually results in a decline in long-term performance. ${ }^{17}$

"Larger-than-life, celebrity leaders who ride in from the outside are negatively correlated with taking a company from good to great," explains Jim Collins in his recent best-selling book. ${ }^{18}$ "The company would show a leap in performance under a talented yet egocentric leader, only to decline in later years." Collins cites that in over two thirds of the comparison cases they studied, the presence of a charismatic CEO with a "gargantuan personal ego" contributed to the demise or continued mediocrity of the company. ${ }^{19}$ As a case in point, consider this assessment of ABB CEO Percy Barnevik by Wall Street Journal reporters Dan Bilefsky and Anita Raghavan: ${ }^{20}$ "Through the ' $90 \mathrm{~s}, \mathrm{ABB}$ was hailed as the General Electric of Europe. Its charismatic chairman and CEO, Percy Barnevik, was compared with GE's Jack Welch and celebrated on the covers of business magazines. Then, 14 months ago, Mr. Barnevik was forced out - with ABB buried in debts and lawsuits and its stock battered. Now the company is trying to carry out a major restructuring, pruning jobs and drastically reducing its size. ABB's decline highlights the perils of relying too heavily on a star manager. Mr. Barnevik's charisma and clear vision for ABB helped turn the company into a world-wide power, but those same qualities left management reluctant to challenge him when they thought he was making a mistake. Mr. Barnevik did an admirable job in the 1990s, but you have to ask what a company looks like in the years after a chief executive steps down. For most of his ABB career, the board - and the market - thought Mr. Barnevik could do no wrong. His personality was as imposing as his 6-foot, 3-inch frame. He made his points so forcefully and eloquently that those with opposing views often gave up. When Percy said something, it was done." Current CEO Jurgen Dormann is now busy dismantling much of the legacy of Percy Barnevik. ABB's share price has dropped to $\$ 2.86$ from $\$ 33$ just three years ago. Morgan Stanley estimates ABB lost \$161 million in 2002 - after losing \$691 million in 2001. ABB's very existence is now at stake. "One of Europe's largest companies, with some $\$ 23$ billion in sales and close to 150,000 employees, will probably be broken up," says Business Week. ${ }^{21}$

The presence of a charismatic leader can have another negative effect: the atrophying of leadership abilities in people elsewhere in the organization. Charismatic leadership necessitates strong centralized rule. ${ }^{22}$ By abdicating leadership responsibilities to the top, the rest of the organization often fails to develop the leadership abilities that necessarily must exist if an organization is to thrive in the long term. Collins' research indicates that charismatic leaders fail to prepare the company for success in the next generation. As a result, their successors faced management teams who had not developed their own leadership skills. ${ }^{23}$ Charismatic leaders with their overpowering personality and vision become the focus of the firm to such an extent that all others in the organization are followers. "Corporations have invested less in developing their own managers as they increasingly look for charismatic leaders to fill their top slots," says a senior partner at an executive search firm. ${ }^{24}$ Convinced that internal management development programs will not produce the type of charismatic leader they need, companies fail to adequately invest in and develop their own leaders. Seeing the bulk of attention and rewards going to a single individual at the top of the organization not only lowers the commitment of others to the organization, but also decreases these individuals' willingness to invest in skills that will help the organization but are not necessarily marketable outside of it, says Khurana. Discussing the disadvantages of 'transformational' leaders in his book Meeting the Ethical Challenges of Leadership: Casting Light or Shadow, Craig E. Johnson says: "So much focus on the leader can create dependency. Followers won't act independently if they continually look to the leader for guidance." 25 Such leader-centric views of how organizations work downplay the contributions of others in the organization. A focus on charismatic leaders loses sight of the fact that many other stakeholders in an organization are just as important to the success of a group as the leader, if not more so. After all, says Johnson, followers do most of the work! Charismatic leaders tend to leave behind an organization that can't be great without them. Successors face a management team so shallow they struggle with talent voids that eventually bring about a decline in performance. "In over three quarters of the comparison companies, we found executives who set their successors up for failure," says Collins. ${ }^{26}$

Some research indicates that there may be times when an organization might benefit from a charismatic Leader. ${ }^{27}$ One of these situations is during an entrepreneurial start-up, when the unique vision of such a Leader truly inspires the organization to move toward a vision others haven't yet grasped ("A computer on every desk and in 
every home, all running Microsoft software"). Another instance is when the organization's very survival is in jeopardy without someone at the top who can "lead the way" with confidence (such as in Lee Iacocca's turnaround of the Chrysler Corp.). However, even in these circumstances one must be concerned with the long-term performance of the company once the enterprise is up and running or the crisis is averted. (Though Iacocca performed one of the most celebrated turnarounds in business history, Chrysler's stock fell 31 percent behind the general market in the second half of his tenure. $)^{28}$ And we all know what eventually happened to Chrysler.

If charismatic qualities are not required in most corporate situations, how did we come to this point? Charisma wasn't always a required characteristic in business leaders. For the three decades following World War II the typical CEO was a professional manager who worked his way up the ranks and was no better known to the general public than his secretary or his dentist. ${ }^{29}$ All that started to change in the 1980s. "Then the 1990s gave rise to the celebrity CEO, the larger-than-life hero who, muscles his way to the top of an organization and, by sheer force of will, remakes it in his own image. But with that myth shattered by the likes of Kenneth Lay, Dennis Kozlowski, Bernard Ebbers, and other disgraced corporate chieftains, it's time to reassess the very nature of leadership." ${ }^{30}$ Forget the flash, forget the charisma, executive recruiters, leadership experts and executives themselves now say. In this post-Enron era of corporate greed, what's needed is a return to what is seen by many as old-fashioned leadership concepts - character and integrity. ${ }^{31}$

\subsection{A More Reasonable View Of Leadership}

Perhaps now that we have seen the problems resulting from the charismatic, Leader-focused approach to running our organizations, we can return to a more reasonable approach that is actually attainable by mere mortals one where many of us are called upon to be good, everyday leaders. There is a wealth of evidence that the solid backbone of organizations that survive - and succeed - over time consists of those managers and individual contributors who "lead quietly" every day. According to the award-winning author, theologian and former ambassador Michael Novak: "The unsung heroes of business are those in middle management. More than anyone else in business, middle managers are the community builders, the main trustees of the integrity and moral practices of the firm. They are its moral and intellectual spine." ${ }^{, 32}$ A recent Wall Street Journal article proclaims: "Make way for astute middle managers. Their power is growing as many find they have more credibility and goodwill from their staffs than do their top bosses. Now is the time for hard-working and trustworthy managers to present themselves as the new face of upper management." 33 "We're back to basics where what counts is honesty and reliability, along with the ability to get results," says the head of executive search firm Cook \& Co. ${ }^{34}$

Everyday leaders can be recognized by the way they confidently and competently go about doing their jobs and in the way they step in (and step up) to leadership roles when required for the good of the organization. They take on a leadership role, not for the status and power it gives them but out of a desire to serve the organization and its constituents. ${ }^{35}$ These are the so-called "Level 5 leaders" described by James Collins: "The key trait of Level 5 leaders [is] ambition first and foremost for the company and concern for its success rather than for one's own riches and personal renown. The good-to-great leaders never wanted to become larger-than-life heroes. They never aspired to be put on a pedestal. They were seemingly ordinary people quietly producing extraordinary results. For these people, work is about what they build, create and contribute, comfortable with the idea that most people won't even know that the roots of that success trace back to their efforts." ${ }^{36}$ When Business Week editors decided to look for leaders who built solid, enduring companies with superior corporate performance over many years, they found that none of them were "change agents" or visionary recent recruits charged with remaking culture or strategy. The one trait these leaders shared was a passion for their companies. These people had led their companies an average of 18 years and worked in them for an average of 26 years. ${ }^{37}$ The Business Week writers said that in these interviews they found an "unusual picture" of what true leadership looks like. Unusual, that is, for reporters who were used to a decade or two of writing about the charismatic, larger-than-life Leader.

Contrast these "good CEOs" who grew up with their companies to the phenomenon Rakesh Khurana describes in his research on the market for external CEOs. He says the development of the external CEO market is an outgrowth of our belief in the idea of the charismatic CEO and profiles examples of organizations that passed up top-caliber internal candidates for external "change agents." His research shows that it is not at all unusual for 
companies to overlook strong internal leaders, that they are "routinely dismissed as unequal to the role of corporate savior or change agent, a figure now seen as the key to reviving troubled companies. Indeed, the preference for glamorous external candidates over qualified insiders has now become so common that we need to be reminded that things were not always so." ${ }^{38}$ I have witnessed this same phenomenon in my years as a corporate recruiter, where managers routinely passed up strong, but not perfect, internal candidates for the lesser-known external "star." In fact what they are doing is trading off known weaknesses for those of an external candidate whom they cannot possible know as well, however thorough and lengthy the recruitment process.

According to Peter Block in his book on stewardship, ideas about "great leaders" only reinforce the belief that accomplishment comes from great individual acts rather than from teams and communities. ${ }^{39}$ Such concepts of leadership don't leave much room for the development - or recognition - of the majority of people making decisions every day within our organizations.

In the preface to his book Leading Quietly, Harvard professor Joseph Badaracco says: "Every profession and walk of life has its great figures, leaders, and heroes. Think of the men and women who create or transform major companies, the political leaders who reshape society.... We exalt these individuals as role models and celebrate their achievements. They represent, we feel, the true model of leadership. But do they really? I ask this because, over the course of a career spent studying management and leadership, I have observed that the most effective leaders are rarely public heroes. These men and women aren't high profile champions of causes and don't want to be.... They move patiently, carefully, and incrementally. They do what is right - for their organizations, for the people around them, and for themselves - inconspicuously and without casualties." ${ }^{40}$ I have come to call these people "everyday leaders."

The vast majority of problems calling for leadership are everyday situations. These situations aren't reserved for people at the top of organizations - anyone can face these challenges at almost any time. Most decisions don't come with 'time out' from everyday work to check with a Leader who has all the answers, they are woven into the fabric of our jobs. ${ }^{41}$ After years of studying leadership in scores of situations, Badaracco describes the successful leaders he found this way: "As individuals, these men and women were modest and unassuming.... They weren't charismatic, had little power and didn't see themselves as leaders in the conventional sense. Their idea of taking action was working behind the scenes - patiently, carefully, and prudently. They handled difficult choices and tough situations in ways that made the world a better place. They view strong measures and heroism as a last resort, not the first choice or the standard model. This is why Navy fliers are told in training that 'there are no old, bold pilots.' What do these patient, unglamorous, everyday efforts add up to? Almost everything." 42

\subsection{The Role Management Education Can Play}

In his conclusions about how to bring a more rational approach to the selection of CEOs, Khurana concludes that two institutions that can play a role in affecting the support and legitimacy that the charismatic CEO model now commands: Professional business education and the business media. He maintains that in their present forms, these two institutions tacitly support the orientation toward charismatic leadership. ${ }^{43}$ We may not be able to do anything about the business press, but we can certainly look at what we are doing in educating future business leaders that may be a contributing factor. ${ }^{44}$ As far back as the 1980s when I received my MBA, I can remember my frustration with classes that focused on case studies and decision-making as if students were corporate CEOs. There was no way I could apply that knowledge to my current position and level of influence in the organization. The implication was that until we reached a position of power, the concepts, skills and tools we were learning about wouldn't really apply. "Written from the point of view of a single CEO protagonist - as are many leadership cases our pedagogical tools can subtly reinforce the charismatic orientation that dominates contemporary discussions of leadership, particularly the assumptions that leadership exists primarily at the CEO level and that individual corporate leaders, especially those at the top of the organizational hierarchy, exercise more control over organizational outcomes than they actually do. ${ }^{, 45}$ 
I believe that if educational institutions (and business organizations) begin to focus on developing the skills and character of everyday leaders, our organizations will not only be far more successful, but surely more trusted than most of them are today. Yes, there have been weak organizations made strong by great Leaders. And there have also been good organizations destroyed by ego-driven Leaders. But the majority of organizations are populated throughout with good, everyday leaders.

So how do we develop everyday leaders? Most college management textbooks teach that the profession of management consists of four basic tasks: planning, organizing, leading and controlling. I'll go into each of these in more detail, but for now want to point out the fact that leading is just one of the four tasks that are required for managers to do a good job! This would seem to indicate that managing is a far more complex job than just being a good leader. You can't be a good manager without being a good leader, but you must also be skilled in the other three areas.

If we are to educate future managers to be effective - and trusted - members of society, then we should expect them to be far more than Leaders with a vision. As any management text would tell you, planning consists of developing a mission and values for your organization. Where does vision fit in? A vision is simply an image or picture of the organization's purpose or mission having been achieved. ${ }^{46}$ Vision isn't something only charismatic Leaders can see, it is the way any good manager communicates the organization's purpose by telling a story or painting a mental picture in a memorable way that workers throughout the organization can relate to, no matter what their job. "Landing a man on the moon in a decade was the vision that John Kennedy held out as a magnet pulling an entire nation to develop the technological capability for manned space flights." ${ }^{47}$ Such a vision certainly is more compelling than saying "We'll be the best in the world in science and technology." It was a way of visualizing what winning the space race would look like.

But planning is much more than communicating purpose. It's stating the goals - or success measures - that you want the organization or your division or department to achieve. It's developing strategies for sustainable competitive advantage. And then it's the unglamorous work of developing the "who, what, when, where and how" of activities to accomplish your goals and strategies and allocating the resources to carry them out. This is one place where our current management textbooks fail us in the development of everyday leaders. In every management text I have reviewed, planning is approached only from the corporate level - corporate mission, corporate strategy, corporate goals. What our students need to learn is how to plan well at whatever level in the organization they find themselves, since the other three tasks of management all flow from the decisions made in the planning process. To fill this gap in my Management Theory course, I have had to develop my own module on Operational Planning, pulled directly from my days as a Corporate Planning Manager teaching new managers how to develop departmental annual plans.

Organizing as a management task is quite different from keeping things orderly and managing your time well (though this is often, mistakenly, what my students think it means). It includes making decisions regarding the structure and relationships of the people within the firm. Who reports to whom? Who has decision-making authority? How will you select and develop the people for your organization? What type of compensation and performance management systems will be used and how should they be implemented? What kind of atmosphere or culture will you cultivate? What is the organization's communication philosophy and what type of communication architecture needs to support it? The answers to these questions all flow from the decisions made in the planning process: your organizational culture develops from the policies and procedures, rites and rituals that managers carry out every day, and they should deliberately support the firm's values and beliefs. There is no one 'right' organizational structure or design - it depends on how you can best achieve organizational goals within the given strategy. (Structure follows strategy, as Peter Drucker instructed us!)

Controlling is perhaps the most misunderstood management task. In the context of management, control does not mean to "rule" or to "have power over." Rather it should consist of an open process of monitoring and measuring performance, comparing it to the desired results (back to the plan again), and then taking corrective action when necessary. Corrective action could be analyzing performance to see what is interfering with achieving the desired goals and then removing impediments, or providing resources to improve performance, or it could be 
changing the plan - maybe it was unrealistic! Control is not about disciplining or firing people who make mistakes, it's about putting in place corrective and preventive measures so organizational goals can be achieved. (Though this may result in disciplining or firing people, it is certainly much more than that.)

That's a thumbnail sketch of the first three tasks of management. (With the exception of the strategic planning piece, many charismatic Leaders are not very skilled at these tasks and, as a result, tend to devalue them as administrative tasks best left the managers. ${ }^{48}$ ) Now let's take a look at the fourth task, leadership. Much has been written about leadership in the last decade or so (At last count Amazon.com listed over 12,000 books with "leadership" in the title). Though I have not found a textbook that clearly outlines the task of leadership in exactly this way, by patching together numerous books, articles and textbooks on the topic of leadership, I tell my students that leadership consists of competency in five areas: motivation, communication, a source of power, trust, and the ability to make effective decisions. My proposition is that we can —and must — develop these competencies in people throughout our organizations.

To be a leader by definition means there are followers. These 'followers' do not need to be people who report to you structurally in the corporate hierarchy. Rather, they are any group of people motivated to work toward a common goal. This requires two things of the everyday leader: first, to communicate his/her idea or goal (or vision) in such a way that others understand it, accept it, and commit to it. ${ }^{49}$ Effective communication - listening, writing, speaking, and dialogue skills such as advocacy and inquiry - are critical and should be developed in all our management students and members of our organizations. Secondly, good leaders find effective ways to cause others to be motivated to exert extra effort toward achieving the desired results. There are many theories when it comes to motivating employees. Some advocate organizational methods, such as pay and other types of reward systems. Others focus on the relationship between a manager and the person s/he wants to motivate. Everyday leaders may or may not have supervisory 'authority' over the potential 'followers' or the ability to influence the structure of organizational pay and reward systems. So how can they go about developing an "energized group of people who are motivated" to work harder than they normally would to achieve some desired goal? Rather than manipulating behavior through artificial reward systems, everyday leaders motivate others by convincing them that the effort is worthwhile in and of itself, to them as individuals as well as for the organization as a whole. Motivation comes from within the individual once $\mathrm{s} / \mathrm{he}$ sees the future state as desirable. Communication skills are thus integral to motivation, because of the necessity for the everyday leader to convince others of the worthiness of the goal.

Let's talk about another concept my students often misinterpret - that of power. In the context of organizational leadership, I am not referring to power as the ability to dominate others, but rather the ability to influence others. Organizational power is "the ability to marshal the human, informational, and material resources to get something done." ${ }^{50}$ Warren Bennis (in an earlier book on leadership, before he wrote about the "differences" between managers and leaders) says that perhaps the most damaging myth about leadership is that the leader "controls, directs, prods, and manipulates." He says: "Leadership is not so much the exercise of power itself as the empowerment of others." ${ }^{51}$ In the executive summary of the recently republished classic article on power, "Power is the Great Motivator" by McClelland and Burnham, the Harvard Business Review editors say: "Nowadays....admitting to a desire for power is a little out of fashion. But....power is essential to good management..... [however] seeking power is not the same as seeking glory. People who want power only to further their own careers, rather than the goals of the organization, tend to have subordinates who are loyal to them but not to the company, making them less effective on the whole. And wanting power is not the same as throwing it around." ${ }^{52}$ To have the opportunity to influence others, there needs to be some reason for them to listen to you and do what you desire. This source of power could come from one's position within the organization or from one's ability to reward or punish employees. But for everyday leaders it is their individual reputation - either as an expert in an area or based on the positive relationships they have built with others in the organization - that gives them the ability to influence others. Referent and expert power (that is, power coming from relationships and specialized knowledge, respectively) are the sources most likely to bring lasting commitment from 'followers' to the task at hand $^{53}$ - so even leaders who have the ability to use other power sources may want to take heed. Leaders are able to align the energies of the organization behind an attractive goal. They "lead by pulling rather than by pushing; by creating achievable, though challenging, expectations and rewarding progress toward them rather than by 
manipulating; by enabling people to use their own initiative and experiences" rather than using their power to deny or constrain others' experiences and actions. ${ }^{54}$

The third leadership competency is trust. This is the factor many of our leaders have lost in the last year. What does it take for any leader to build trust? Can it be regained once lost? Robert Bruce Shaw defines trust in his book Trust in the Balance as "the belief that those on whom we depend will meet our expectations of them. Trust," he says, "is more than simple confidence, but less than blind faith." 55 The three elements of trust, as he describes them, are acting with integrity, demonstrating concern, and achieving results. By acting with integrity he means honesty in one's words and consistency in one's actions. Do what you say you will do, in other words, and do what is ethical and right. This means having certain values one lives by, and acting on them in business as well as in our personal lives. Talk is cheap; everyday leaders need to "walk the talk" if they want to be trusted. It means acting ethically and expecting that others in the organization will do the same, rather than talking the values game but encouraging a culture that expects people to search for loopholes and shortcuts to 'get away with' as much as possible. It means doing what is right - even if it means missing short-term objectives - because you are laying the groundwork for long-term success.

Demonstrating concern for others is Shaw's second condition for trust. "At its most basic level, we trust those who care about us. We trust those whom we believe understand our concerns and will act in a way that meets, or at least does not conflict with, our needs." ${ }^{56}$ But Shaw goes on to say that this element of concern goes beyond caring for employees as individuals to include showing a concern for 'the whole,' whether our work group or our organization. "She is not working any personal agenda but truly wants what is best for the company," is a comment often used when people describe everyday leaders.

The last element of trust is that of achieving results. "Many make the mistake of viewing trust as a soft issue that is detached from hard business realities," says Shaw. ${ }^{57}$ Trust, however, requires that we believe our leaders are willing and able to meet their commitments to us. This means making decisions on a regular basis that prove to be correct and on target. In the absence of a track record to this effect, a leader must convince others that $\mathrm{s} /$ he has the requisite skills and competencies to deliver the expected results. Even if a leader demonstrates concern and has integrity, s/he will not retain our trust if they are incompetent or unable to fulfill the expectations we have of them. This is a matter of skill and experience that enables effective decisions to be made - and as such, capabilities that we should be able to teach and aspiring leaders should be able to learn. This includes competence in certain technical or professional areas that are critical for the organization as well as basic problem-solving skills.

Building trust does not happen over night; it is built over time by making effective decisions that deliver the desired results, living up to one's word, acting ethically and honestly, and demonstrating true concern for others and the organization as a whole. Once lost, trust is very difficult to regain, as many of our business organizations are discovering.

Let's begin the work of developing ethical and competent everyday leaders for our organizations. Sure, some of our students will become presidents or CEOs someday. But by far the majority will become the managerial backbone that organizations need to stand tall in serving their varied stakeholders. A recent Washington Post article concludes that students are less ethical (and therefore, less trustworthy) after attending business school. ${ }^{58}$ This would seem to indicate we are not teaching the right things, or at least not teaching them very well. Perhaps part of the problem is that we teach them all as if they must become CEOs or at least top executives if they are to be considered 'successful.' They feel they need to stand out, to make their mark...to be a Leader. As a result, they may without realizing it fall into an ego-centric, power-hungry pattern of behavior, willing to do almost anything to prove they are worthy of being crowned Leader. What we should focus on is developing good, competent and trustworthy everyday leaders who can keep our organizations running successfully for the long-term rather than trying to develop stars that burn hot and bright, but fade out fast and destroy much along their path. FORTUNE magazine has announced that "The era of the dominant CEO died a quick and painful death, and it will be a long time before it comes back." ${ }^{.59}$ Let's hope so. 
Harvard professor Joseph Badaracco says that an everyday approach to leadership is easy to misunderstand. "It doesn't excite or thrill. It provides no story lines for television dramas" ${ }^{60}$ or fodder for business writers hoping to publish an attention-grabbing article or sell the next new book on Leadership. Everyday leaders may not leave a bold mark on history because they work on a different scale. Their efforts may not be recorded by the business press, but they matter. They matter because it is the everyday leaders who keep our companies and our countries running. And this is why it is so important that we teach them well.

As for the best leaders, the people do not notice their existence; the next best, the people honor and praise; the next, the people fear; and the next, the people hate. When the best leader's work is done, the people say 'We did it ourselves!'” Lao Tzu

\footnotetext{
${ }^{1}$ Rakesh Khurana explains that - despite the lack of a convincing link between the CEO and corporate performance - firms continue to buy into the mythology that the key to improving long-term firm performance is hiring the right CEO. Rakesh Khurama, Searching for a Corporate Savior: The Irrational Quest for Charismatic CEOs, (Princeton, New Jersey: Princeton University Press, 2002), 190.

2 Abraham Zaleznik, "Managers and Leaders: Are They Different?” Harvard Business Review, May-June vol. 64 (1986): 4849.

${ }^{3}$ Warren Bennis, On Becoming a Leader (Addison-Wesley Publishing Company, Inc.1989), 44-45.

${ }^{4}$ Khurana says corporate directors and search consultants use words such as "chemistry," "executive presence," "articulation," "stature," and "change agent" to describe a candidate's charisma. Sociologist Max Weber said the charismatic leader is regarded as "all powerful and all wise." Some authors use the term "transformational" leader, but usually reference similar characteristics, such as: "Transformational leaders' influence rests on their ability to inspire others through their words, visions and actions." Hellriegel, Jackson, and Slocum textbook, Management, $8^{\text {th }}$ Edition. Compare this with Robbins \& Coulter's Management $7^{\text {th }}$ Edition text definition of charismatic leader: "An enthusiastic, self-confident leader whose personality and actions influence people to behave in certain ways."

${ }^{5}$ Anthony Bianco ,"The Fall of an Icon," Business Week, September 23, 2002, 46.

6 “Another Crop of Sleazy CEOs," Business Week, August 26, 2002, 12. Quoting Dean Stamoulis, executive director at Russell Reynolds and an organizational psychologist, commenting on the results of the psychological profiles conducted on more than 1,400 managers at large US companies.

${ }^{7}$ James McGregor Burns, Leadership (New York: HarperCollins, 1978)

${ }^{8}$ Peter Block, Stewardship: Choosing Service Over Self-Interest (San Francisco: Berrett-Koehler Publishers, 1993), 14-15.

${ }^{9}$ Khurana, Searching for a Corporate_Savior, 69

${ }^{10}$ Ibid.

${ }^{11}$ Ibid.

${ }^{12}$ Weber (1947) "Economy and Society," as discussed by Khurana in Chapter 6 of his book Searching for a Corporate Savior.

${ }^{13}$ William H. Whyte, The Organization Man, (New York: Simon and Schuster, 1956).

${ }^{14}$ Khurana, Searching for a Corporate Savior, 71.

${ }^{15}$ Peter M. Senge, “The Leader's New Work: Building Learning Organizations,” Sloan Management Review, Fall 1990, Vol. 32 , No. 1, 8-9.

${ }^{16}$ Khurana, Searching for a Corporate Savior, 26. Khurana cites a previously published work (1996) with Nohria titled "Substance and Symbol."

${ }^{17}$ Ibid.

${ }^{18}$ Jim Collins, Good to Great (New York: HarperCollins Publishers Inc., 2001), 10.

${ }^{19}$ The cases where Collins found that a charismatic CEO eventually become a liability for the company were Great Western, Warner-Lambert, Scott Paper, Bethlehem Steel, R.J. Reynolds, Addressograph-Multigraph, Eckerd, Bank of America, Burroughs, Chrysler, Rubbermaid, and Teledyne. Good to Great, 265.

${ }^{20}$ Dan Bilefsky and Anita Raghavan, The Wall Street Journal, January 23, 2003, 1.

${ }^{21}$ Business Week, February 10, 2003, “Work Your Magic, Herr Dormann: ABB faces meltdown—so this CEO isn't wasting any time," 46.

${ }^{22}$ Khurana, Searching for a Corporate Savior, 196.

${ }^{23}$ Collins, Good to Great, 26-27.

${ }^{24}$ Khurana, Searching for a Corporate Savior, 196. Khurana quotes a senior partner at the executive search firm Russell Reynolds, who asked to remain anonymous, in explaining that his firm's business has grown dramatically in recent years because of the failure of companies to invest in and develop their own managers.

${ }^{25}$ Craig E. Johnson, Meeting the Ethical Challenges of Leadership: Casting Light or Shadow (Thousand Oaks, CA: Sage Publications, 2001), 127.

${ }^{26}$ Ibid. 26.
} 
${ }^{27}$ Stephen P. Robbins and Mary Coulter, Management $7^{\text {th }}$ edition (New Jersey: Prentice Hall, 2002), 472.

${ }^{28}$ Collins, Good to Great, 29.

${ }^{29}$ Khurana, "Curse of the Superstar CEO," 62.

${ }^{30}$ Nanette Byrnes, John A. Byrne, Cliff Edwards, Louise Lee, Stanley Holmes, and Joann Muller, "The Good CEO," Business Week, September 23, 2002, 80.

${ }^{31}$ Patricia Kitchen of Newsday, "Distrust creates demand for new leaders," The Holland Sentinel, October 13, 2002 C1.

${ }^{32}$ Michael Novak, Business as a Calling: Work and the Examined Life (New York: The Free Press, 1996), 28-30.

${ }^{33}$ Carol Hymowitz, "Middle Managers Find Their Skills, Integrity Now Carry More Weight," The Wall Street Journal, July 30, 2002, B1.

${ }^{34}$ Ibid.

${ }^{35}$ Robert K. Greenleaf, Servant Leadership (New York: Paulist Press, 1977), 13.

${ }^{36}$ Collins, Good to Great, 25-36.

${ }^{37}$ Byrnes, "The Good CEO," 81. This study was based on companies that had exemplary earnings and sales growth both over time and against their peers. The companies of each of the CEOs they selected outperformed the broader market, some by huge percentages. They also included measures of management skill, such as return on invested capital.

${ }_{38}^{38}$ Khurana, Searching for a Corporate Savior, 50-51.

${ }^{39}$ Block, Stewardship, 13.

${ }^{40}$ Joseph L. Badaracco, Jr. Leading Quietly: An Unorthodox Guide to Doing the Right Thing (Boston: Harvard Business School Press, 2002), 1.

${ }^{41}$ Ibid. 5.

${ }^{42}$ Ibid. 7, 9.

${ }^{43}$ Khurana, Searching for a Corporate Savior, 212.

${ }^{44}$ Ibid. 125. Khurana says that MBA training at elite business schools has shifted focus over the past several decades from that of training managers for specific functions to producing "general managers."

45 Ibid. 214. Khurana further proposes that an increased emphasis on cases involving non-CEO leaders and drawing on the perspectives of multiple protagonists might be one way of counteracting the idea that a single individual's actions can solve the complex problems with which leaders are usually faced.

${ }^{46}$ George Land and Beth Jarman, "Future Pull: The Power of Vision and Purpose," The Futurist, July-August 1992, 25.

${ }^{47}$ Ibid.

48 The key behaviors required of charismatic leaders, as described it textbooks such as Management by Hellriegel, Jackson and Slocum are "Vision, framing, and impression management."

${ }^{49}$ Carl F. Frost, Scanlon Plan principles as described in Changing Forever: The Well-Kept Secret of America's Leading Companies (East Lansing, Michigan: Michigan State University Press, 1996).

${ }^{50}$ Morgan McCall Jr., "Power, Influence, and Authority: The Hazards of Carrying a Sword," Technical Report, 10 (Greensboro, NC: Center for Creative Leadership, 1978), 5.

${ }^{51}$ Warren Bennis and Burt Nanus, Leaders (New York: Harper \& Row, Publishers, Inc., 1985), 224-225.

${ }^{52}$ Harvard Business Review, January 2003, 142. Editor's executive summary of the 1976 HBR article "Power Is the Great Motivator" by David C. McClelland and David H. Burnham.

${ }^{53}$ Don Hellriegel, Susan E. Jackson, and John W. Slocum, Jr., Management $8^{\text {th }}$ Edition (South-Western College Publishing, 1999). 502.

${ }^{54}$ Bennis, Leaders, 225.

${ }^{55}$ Robert Bruce Shaw, Trust in the Balance (San Francisco: Jossey-Bass Publishers, 1997), 21, 29.

${ }^{56}$ Ibid., 32.

${ }^{57}$ Ibid., 30.

${ }^{58}$ Amitai Etzioni, "When It Comes to Ethics, B-Schools Get an F," The Washington Post, August 4, 2992 , p. B4.

${ }^{59}$ Eric Dash, "Cleanup Time," FORTUNE, September 16, 2002, 64.

${ }^{60}$ Badaracco, Leading Quietly, 178. 